\title{
Peranan School Well-Being pada Flow Akademik Siswa Sekolah Menengah Pertama
}

\author{
(The Role of School Well-Being in Academic Flow \\ Of Junior High School Students)
}

\author{
Ramon Ananda Paryontri*, Ghozali Rusyid Affandi, dan Sulis Suprapti \\ Fakultas Psikologi dan Ilmu Pendidikan, Universitas Muhammadiyah Sidoarjo, Indonesia \\ ${ }^{*}$ ramon.ananda@umsida.ac.id
}

\begin{abstract}
Abstrak
Penelitian ini bertujuan untuk mengetahui hubungan antara school well-being dengan flow akademik. Populasi dalam penelitian ini adalah seluruh siswa SMP X sebanyak 176 siswa dan total sampel berdasarkan tabel Isaac dan Michael dengan taraf kesalahan sebesar 5\% yaitu sebanyak 114 siswa dengan teknik sampling proportionate stratified random sampling. Pengumpulan data penelitian menggunakan 2 skala psikologis yaitu skala school well-being dan skala flow akademik. Analisis data penelitian menggunakan korelasi product moment dan regresi. Hasil analisis menunjukkan, bahwa school well-being mempunyai hubungan positif dengan flow akademik $(r=0.773, \mathrm{p}=0.000<0.001)$. Hasil analisis juga menunjukkan bahwa loving (relasi dengan orang lain) memiliki hubungan yang paling tinggi dengan flow akademik jika dibandingkan dengan aspek school well-being yang lainnya. Hasil uji regresi menunjukkan bahwa school well-being memiliki pengaruh yang signifikan terhadap flow akademik siswa SMP $(\mathrm{F}=166.349, \mathrm{p}=0.000<0.001)$ sebesar $59,8 \%$ dengan koefisien regresi sebesar $\beta=0.401$.
\end{abstract}

Kata Kunci: School Well-Being, Flow Akademik, Siswa Sekolah Menengah Pertama.

\begin{abstract}
This study aims to determine the relationship between school well-being and academic flow. The population in this study were all students at X Junior High School, which were 176 students. The total sample was based on Isaac and Michael's table with an error rate of 5\%, which were 114 students who were chosen using proportionate stratified random sampling technique. The research data collection uses 2 psychological scales, namely the school wellbeing scale and the academic flow scale. Product moment correlation was used to analyze the main hypothesis. The results of the analysis show that school well-being has a positive relationship with academic flow $(r=0,769, p=0.001)$. The higher their school well-being, the higher they gained scores on academic flow. The results of the $R$ Square test obtained results of 0.59, which means that the magnitude of the influence of school well-being on students' academic flow is $59.1 \%$.
\end{abstract}

Keywords: School Well-Being, Academic Flow, Students of Junior High School

\section{PENDAHULUAN}

Pendidikan merupakan salah satu sarana yang digunakan untuk mengembangkan kemampuan yang dimiliki oleh para siswa agar dapat berkembang optimal dan merasakan keadaan flow saat melaksanakan kegiatan akademiknya. Flow akademik sendiri merupakan individu yang dapat fokus, menikmati, dan merasakan adanya dorongan dari dalam dirinya untuk mengerjakan tugas akademiknya (Yuwanto, 2013). Tugas-tugas akademik siswa yang dimaksud adalah mengikuti semua tahapan belajar dan pembelajaran di kelas serta mengerjakan tugas yang menjadi tanggung jawabnya. Sekolah Menengah Pertama (SMP) merupakan sekolah yang memiliki 
kegunaan sebagai wadah untuk mencari ilmu, pengembangan diri siswa, pembentukan moral, pembentukan karakter, serta pengembangan minat dan bakat yang dimiliki siswa (Santrock, 2007).

Siswa yang mengalami flow akan lebih aktif untuk terlibat di dalam kegiatan belajar, mencapai peningkatan mutu di bidang akademik, lebih antusias saat diberi tugas yang cukup sulit, dan cenderung lebih baik dan fokus dalam hal perhatian, mood serta motivasi dalam belajar dibanding para siswa lain yang tidak mengalami flow (Shernoff, Schneider, Csikzentmihayli, \& Shernoff, 2003). Hasil studi yang dilakukan oleh Prihandijani (2016) menjelaskan bahwa flow akademik memiliki dampak yang sangat besar terhadap siswa terkait dengan motivasi berprestasi dan dukungan sosial. Studi ini juga didukung oleh Putri (2016) yang juga menjelaskan bawah flow akademik berkorelasi positif dengan dukungan sosial dan prestasi belajar. Penelitian tersebut juga menemukan bahwa flow akademik dapat mengatasi permasalahan stres akademik. Studi yang dilakukan oleh Gatari (2020) yang menguji mahasiswa di Fakultas Psikologi Universitas Muhammadiyah Malang menunjukkan kontribusi dari stres akademik terhadap flow akademik yaitu sebesar $12,9 \%$.

Flow akademik merupakan salah satu konstrak yang berperan besar dalam pencapaian tujuan akademik yang baik. Flow akademik merupakan kondisi di mana individu mengalami suatu kebahagiaan ketika belajar hingga indiviu mengalami puncak prestasi. Siswa yang memiliki flow akademik merasakan adanya semangat untuk melakukan aktivitas belajar sehingga siswa dapat menangkap informasi yang diberikan guru kepada para siswa (Salanova, Bakker, \& Llorens, 2005). Siswa merasa adanya enjoyment (kenikmatan) dalam proses pembelajaran yang dilakukan karena ketika siswa berada pada kondisi flow terdapat energi positif yang muncul dalam dirinya yang dapat meningkatkan kualitas hidupnya. Keadaan flow muncul ketika seorang siswa mengerjakan aktivitas berkaitan dengan bidang akademik, contohnya ketika siswa mengikuti tahapan belajar dan pembelajaran di ruang kelas serta mengerjakan semua tugas yang ada serta terlibat dalam pembelajaran secara penuh (Parman, 2019). Flow diketahui mempunyai efek positif terhadap performa belajar siswa. Studi mengenai flow semakin berkembang baik ketika membahas flow dalam tema sendiri ataupun dikaitkan dengan tema-tema yang lainnya. Beberapa hasil studi mengenai flow telah dilakukan dan dikaitkan dengan tema lain seperti religiositas (Alfarabi, 2017), dukungan sosial (Putri, 2016), dan self efficacy (Santoso, 2014). Dukungan sosial, religiusitas dan self efficacy merupakan variabel yang berkorelasi positif dalam beberapa penelitian yang meneliti dan mengaitkannya dengan variabel flow akademik. Flow sudah mulai diterapkan di beberapa lembaga pendidikan seperti di sekolah Montessori dan digunakan untuk mengevaluasi tugas-tugas yang dilakukan siswa sekaligus menciptakan lingkungan yang positif di sekolah (European Commission, 2014).

Kenyataan di lapangan menunjukkan masih terdapat siswa yang memiliki flow akademik yang rendah. Alfarabi (2017) menemukan bahwa flow akademik siswa berada pada kategori rendah dengan persentase 42, 8\% (Alfarabi, 2017). Penelitian lain yang dilakukan pada siswa Sekolah Tinggi Teknologi Angkatan Darat (STTAD) menunjukkan bahwa 50,8\% dari siswa STTAD berada pada kategori flow yang rendah (Prihandrijani, 2016). Hal ini dapat menguat asumsi bahwa masih ditemukan banya siswa mempunyai flow akademik yang rendah. Dampak dari siswa yang memiliki flow akademik yang tergolong rendah adalah adanya antusiasme yang rendah pula ketika mengikuti tahapan belajar dan tahapan penyelesaian tugas bidang akademiknya (Prihandrijani, 2016). Padahal, kedua proses ini akan berdampak pada proses pembelajaran siswa. Hal ini membuat pendidik, wali siswa/orang tua dan siswa sendiri perlu mencari langkah dalam mengatasi dan mencegah kendala serupa di masa depan.

Masalah flow akademik yang rendah juga terjadi pada siswa di SMP X Sidoarjo. Berdasarkan wawancara oleh peneliti pada tanggal 10 Juni 2021 
pukul 11.00 WIB kepada tiga orang guru di SMP tersebut, ditemukan bahwa terdapat beberapa siswa yang memiliki masalah dalam indikator-indikator perilaku dalam flow akademik seperti kurang konsentrasi, kurang mau terlibat dalam segala proses pembelajaran, dan kurang fokus dalam menyimak materi yang diberikan dari guru. Responden guru A mengatakan:

"Siswa-siswi di sini sangat susah untuk dapat bersemangat dalam belajar, biasanya banyak mainnya terus malas-malasan apalagi kalau sudah banyak kegiatan di sekolah. Pernah njih, suatu waktu saya tegur dan saya ya berusaha mencari cara supaya ada aturan yang mengatur para siswa-siswa yang bermasalah itu. Tapi ya hasilnya tetap aja mas, gak mempan. Perlu ada kebijakan khusus di sekolah mengenai hal ini terkait dengan regulasi yang jelas."

Responden guru B menjelaskan terkait dengan flow akademik pada siswa di SMP X Sidoarjo yang masih rendah yang ditunjukkan dengan minimnya keterlibatan siswa di kegiatan.

"Siswa di sini susah untuk dilibatkan dalam proses belajar yang baik, mas. Ya, bisa dilihat dalam proses belajar mereka. Mereka ya, kalau di kelas sering rame dan tidak mau jika ada tugas baik sendiri maupun tugas kelompok mas. Jika ditanyai oleh saya, pasti mereka juga gak ada yang jawab begitu. Saya kadangkadang sampai kehabisan ide untuk ngembangin metode apa yang cocok buat mereka ya."

Responden guru C menjelaskan tentang rendahnya flow akademik terkait dengan kurang fokus dalam menerima materi dari guru:

"Sama kayak di sekolah-sekolah lain pada umumnya seh mas., siswa-siswa di sini ratarata kesulitan jika menyimak dan nerima materi yang disampaikan guru-guru di sini. Dijelaskan berkali kali terkadang ya gitu masih belum dong. Perlu ekstra seh menurut saya kalau menyampaikan materi ke para siswa. Siswa di sini ya macam-macam karakternya: Ada yang cepet, ada yang lambat. Kita sebagai guru harus bisa menyesuaikan kadang-kadang. Siswa dijelasin dalam waktu 10-15 menit saja sudah ke mana mana fisik dan pikirannya."
Hal ini juga sesuai dengan hasil pra-survey yang dilakukan peneliti secara random pada tanggal 10 Juni 2021 terhadap 15 sampel siswa SMP Muhammadiyah 10 Sidoarjo yang terdiri dari kelas VII, VIII, dan IX dengan menggunakan skala Flow akademik (Salanova, Bekker,dan Llorens, 2006). Hasil dari survey awal dengan menggunakan skala flow akademik tersebut menunjukkan 15,0\% flow akademik siswa berada pada kategori tinggi, 44,8\% flow akademik siswa berada pada kategori sedang, $33,8 \%$ flow akademik siswa berada pada kategori kurang, dan 6,4\% flow akademik siswa berada pada kategori rendah. Pada distribusi ini dapat dilihat bahwa siswa-siswi yang berada di kategori kurang dan rendah cukup dominan yaitu sebesar 33,8\% dan 6,4 \%. Hal ini menunjukkan adanya indikasi perilaku flow akademik yang rendah di SMP X Sidoarjo. Indikasi tersebut, sesuai dengan sebaran distribusi di atas, lebih mengarah pada indikator kurang konsentrasi, kurang fokus, dan kurang pelibatan diri ketika pelajaran berlangsung. Hasil studi awal ini kontras dengan hasil penelitian yang telah dipaparkan di atas terkait dengan keadaan flow akademik pada siswa. Studi SMP X Sidoarjo telah memperlihatkan keadaan yang negatif ketika siswa tidak berada dalam kondisi flow dan perlu dilakukan beberapa pendekatan belajar supaya siswa mencapai pada kondisi flow. Hasil penelitian yang dilakukan Aini, Ilfiandra, dan Saripah (2019) menemukan bagaimana metode Montessori dapat membantu siswa untuk berkonsentrasi penuh dan memiliki motivasi untuk terlibat secara penuh dalam proses belajarnya. Hal ini menguatkan perlunya upaya meningkatkan flow akademik siswa SMP X Sidoarjo tersebut dengan cara mengetahui hal-hal apa saja yang mempengaruhi tinggi rendahnya flow akademik siswa.

Terdapat tiga faktor utama yang memengaruhi terjadinya flow akademik siswa (Rubini \& Utami, 2015). Faktor yang pertama adalah immediate and clear feedbacks, di mana semua kegiatan akademik dapat dipastikan terlaksana sesuai dengan tujuan akademik yang ingin diraih dan bisa berjalan dengan baik. Selama mengalami flow, maka umpan 
balik harus diberikan. Feedback mengacu pada adanya informasi-informasi yang harus diberikan secara jelas dan diberikan secara langsung, serta cepat, supaya bisa meyakinkan bahwa jika keseluruhan rencana berjalan sudah sesuai rencana sepanjang flow. Feedback meliputi informasi yang cukup jelas tentang keberhasilan serta kegagalan siswa selama menjalankan tugas akademiknya. Faktor yang kedua yaitu faktor perceived challenge, di mana terdapat perasaan seimbang antara tuntutan situasi dan keterampilan pribadi, di mana siswa bisa melibatkan dirinya dalam mengerjakan tugas-tugas akademiknya. Faktor yang ketiga adalah experience of activity as intrinsical rewarding, di mana kegiatan yang sedang dilakukan didasarkan bukan karena siswa ingin mendapatkan penghargaan dari pihak lain tetapi merupakan kemauan pribadi siswa sehingga kegiatan yang dilakukan terasa olehnya lebih lama ataupun lebih cepat.

Pandangan siswa terhadap sekolah dapat menjadi penentu kesuksesan akademik siswa selama proses belajar di sekolah. Pandangan siswa inilah yang disebut sebagai school well-being, yaitu suatu penilaian siswa yang bersifat subjektif tentang kondisi fisik lingkungan di sekolahnya (Konu \& Rimpelä, 2002). School well-being memiliki dampak luar biasa terhadap peningkatan flow akademik siswa yang dapat membantu siswa untuk mau terlibat selama proses pembelajaran, mampu meningkatkan konsentrasi, dan mampu nyaman terhadap keadaan sekolah. Hal ini didukung oleh Satici (2020) yang menjelaskan bahwa lingkungan yang aman untuk belajar berdampak pada perkembangan yang baik pada siswa sehingga siswa dapat tumbuh dan berkembang secara baik, serta mengeluarkan potensi yang dimiliki. School well-being erat kaitannya denga flow akademik yang meliputi adanya determinasi diri, ketertarikan terhadap diri sendiri dan sekolahnya, serta adanya peningkatan kompetensi. Proses terjadinya school well-being sangat lama yang dimulai dari munculnya perasaan senang, muncul kepuasan, munculnya determinasi diri (keinginan kuat untuk melakukan banyak hal), mulai tertarik dengan lingkungan sekolah hingga output-nya muncul semangat tinggi dalam kegiatan akademik.

Penilaian siswa yang bersifat subjektif tentang kondisi fisik lingkungan di sekolahnya merupakan suatu kondisi, yang memberi kemungkinan untuk individu tersebut bisa memenuhi kebutuhankebutuhan dasarnya selama melaksanakan kegiatan pembelajaran di sekolah. Kebutuhan- kebutuhan dasar siswa tersebut termasuk diri dari aspek having, loving, being, dan health (Konu \& Rimpelä, 2002). Saat tujuan akademik tercapai dengan maksimal dan lingkungan sekolah bagus dan nyaman, maka school well-being dapat berfungsi dalam membantu tercapainya tujuan akademik tersebut (Konu \& Rimpelä, 2002). Dengan demikian, pihak sekolah mampu memberikan kebutuhan dasar yang diperlukan oleh para siswa selama mereka berada di lingkungan sekolah sehingga siswa bisa memiliki school well-being.

Pembaruan dalam penelitian ini adalah terletak pada subjeknya yang merupakan siswa SMP yang berbeda penelitian-penelitian sebelumnya, yang mengambil subjek siswa SMA bahkan mahasiswa. Karakteristik anak SMP dengan SMA dan mahasiswa tentu berbeda dilihat dari perkembangan sosial, kognitif, dan emosi. Penelitian yang dilakukan oleh Mubasyiroh ( 2017) terkait menyebutkan bahwa perbedaan siswa SMP dan SMA ini dilihat dari kemampuan dalam mengontrol emosi, mengolah kreativitas, dan mengelola diri menjadi lebih baik. Siswa SMP memiliki tingkat kematangan yang lebih rendah dibandingkan siswa SMA (Sentana \& Kumala, 2017). Tingkat kematangan yang rendah itulah yang membuat peneliti tertarik mengambil subjek SMP karena ingin melihat flow akademik yang lebih kompleks. Perbedaan karakteristik itulah yang menjadi pertimbangan peneliti untuk mengambil subjek SMP sebagai bagian dari pembaruan/novelty dari penelitian ini.

Mengacu pada permasalahan mengenai flow akademik pada siswa SMP X Sidoarjo serta hubungannya dengan school well-being seperti yang telah diuraikan di atas, serta permasalahan yang telah disebut sebelumnya, peneliti merasa 
perlu melakukan penelitian lebih lanjut. Peneliti merasa tertarik untuk lebih tahu dan berusaha menjelaskan apakah antara school well-being dengan flow akademik memiliki hubungan atau tidak sehingga bisa meningkatkan flow akademik siswa. Siswa diharapkan bisa memiliki kemampuan berkonsentrasi penuh, bisa merasakan kesenangan dan bahagia, mempunyai motivasi yang tinggi dari dalam diri saat melakukan aktivitas pembelajaran dan penyelesaian tugas akademiknya sehingga diharapkan kemampuan yang ada pada diri siswa dapat berkembang secara optimal, sehingga tidak menghambat prestasi dalam belajar dan tujuan belajar dapat tercapai dengan hasil yang maksimal.

Berdasar pada permasalahan tersebut maka, peneliti tertarik untuk mengkaji secara empiris dengan melakukan sebuah penelitian yang berjudul "Hubungan Antara School Well-Being dengan Flow Akademik pada Siswa SMP X Sidoarjo".Tujuan dari penelitian ini adalah untuk mengetahui Hubungan Antara School Well-Being dengan Flow Akademik pada Siswa SMP X. Manfaat penelitian bagi Siswa diharapkan dapat memberikan informasi tentang kontribusi school well-being dan flow akademik pada Siswa. Bagi pendidik, diharapkan dapat memberikan informasi dan masukan dalam meningkatkan kenyamanan belajar siswa. Selain itu, bagi sekolah, diharapkan dapat memberikan informasi dan juga data yang telah teruji secara ilmiah sehingga sekolah bisa menjadikannya sebagai referensi dalam melakukan pengelolaan dan peningkatan kualitas lingkungan sekolah khususnya kondisi fisik di dalam kelas, dan bagi ilmu psikologi, diharapkan bisa memberikan manfaat efektif yang positif untuk meningkatkan dan mengembangkan ilmu pengetahuan dan dapat mejadi rujukan pada bidang ilmu psikologi pendidikan.

\section{METODE}

Pada penelitian ini, penulis menggunakan pendekatan kuantitatif yang bertujuan untuk mengetahui kekuatan dan arah hubungan antara variabel yang mempunyai kaitan dengan variabel lainnya. Variabel-variabel yang digunakan dalam penelitian ini adalah variabel predictor yaitu flow akademik dan variabel outcome yaitu school wellbeing. Penelitian ini menggambarkan keterkaitan positif antara variabel X (school well-being) dengan variabel Y (flow akademik). Pengukuran flow akademik siswa dalam penelitian ini menggunakan skala flow akademik yang dikembangkan oleh peneliti dengan mengacu pada aspek absorption, enjoyment, dan intrinsic work motivation yang dibuat oleh Salanova, Bakker, dan Llorens (2006). Pengukuran school well-being siswa menggunakan skala school well-being yang dikembangkan peneliti dengan mengacu pada konstrak having, loving, being, serta health yang dikembangkan oleh Konu dan Rimpelä (2002).

Populasi pada penelitian ini sebanyak 176 siswa dari SMP X di Sidoarjo kelas VII, XIII, IX. Sampel yang ditentukan dan dipilih untuk penelitian ini ditentukan berdasarkan tabel Isaac dan Michael dengan taraf kesalahan 5\%, yaitu sebesar 114 siswa. Teknik sampling yang digunakan dalam penelitian ini adalah proportionate stratified random sampling. Teknik pengumpulan data dalam penelitian ini dilakukan dengan menggunakan 2 skala psikologi yaitu skala school well-being dan skala flow akademik dengan model penskalaan likert. Penulis menggunakan empat pilihan jawaban, yaitu sangat setuju (SS), setuju (S), tidak setuju (TS) dan juga sangat tidak setuju (STS). Skala Likert juga berisi item favorable (mendukung) dan unfavorable (tidak mendukung). Item favorable mendapatkan nilai yang bergerak dari 4 sampai 1, sedangkan item unfavorable mendapatkan nilai yang bergerak dari 1 sampai 4.

Validitas isi dalam penelitian ini menggunakan pertimbangan dari professional judgement. Proses pengujian validitas penelitian ini dalam pelaksanaannya menggunakan sampel penelitian yaitu 114 responden dengan bantuan program Jeffrey's Amazaing Statistics Programme (JASP). Pada skala flow akademik didapatkan bahwa daya diskriminasi item bergerak dari angka 0,314 - 0,634 dan koefisien reliabilitas (cronbach's alpha) sebesar $r_{\mathrm{xy}}=0,897$. 
Adapun skala school well-being memiliki daya diskriminasi item antara 0,333 - 0,709 dengan koefisien reliabilitas (cronbach's alpha) sebesar $r_{\mathrm{xy}}=$ 0,926 . Analisis data dalam penelitian ini, menggunakan metode statistik korelasi product moment dan regresi sederhana dengan menggunakan bantuan program JASP.

\section{HASIL}

Hasil uji kategorisasi skor subjek dapat dilihat pada Tabel 1. Dapat dilihat bahwa sebagian besar siswa mempunyai school well-being yang dan flow akademik yang cenderung rendah karena persentase terbesar dan jumlah siswa paling banyak berada di kategorisasi rendah.

Tabel 1. Kategori skor subjek pada variabel School Well-Being dan Flow Akademik

\begin{tabular}{lcccc}
\hline \multirow{2}{*}{ Kategori } & \multicolumn{2}{c}{ School Well-Being } & \multicolumn{2}{c}{ Flow Akademik } \\
\cline { 2 - 5 } & $\mathbf{n}$ & $\mathbf{\%}$ & $\mathbf{n}$ & $\mathbf{\%}$ \\
\hline Sangat Rendah & 6 & $5 \%$ & 6 & $5 \%$ \\
Rendah & 77 & $68 \%$ & 80 & $70 \%$ \\
Tinggi & 24 & $21 \%$ & 16 & $14 \%$ \\
Sangat Tinggi & 7 & $6 \%$ & 12 & $11 \%$ \\
Total & 114 & $100 \%$ & 114 & $100 \%$ \\
\hline
\end{tabular}

Uji normalitas pada penelitian ini dilakukan dengan uji one sample Kolmogorov-smirnov pada Residual dari hubungan antara school well-being dengan flow akademik dengan bantuan program SPSS for windows. Berdasarkan hasil uji normalitas diketahui bahwa residual antara school well-being dengan flow akademik terdistribusi normal (KS-Z=
0,550 dan $\mathrm{p}=0,923(\mathrm{p}>0,05)$. Pada hasil uji linearitas diketahui bahwa pada linierity, nilai $\mathrm{F}=$ 195,791 dan $\mathrm{p}=0,000(\mathrm{p}<0,01)$ dan pada Deviation from linierity, nilai $\mathrm{F}=1,413$ dan $\mathrm{p}=0,098(\mathrm{p}>$ $0,05)$, hasil tersebut membuktikan bahwa asumsi linearitas antara antara school well-being dengan flow akademik terpenuhi.

Tabel 2. Hasil uji korelasi antara School-Well Being dan Flow Akademik

\begin{tabular}{lcccccccc}
\hline & SWB & Being & Health & Having & Loving & FA & Absorption & Enjoyment \\
\hline SWB & - & & & & & & & \\
Being & $0.929^{*}$ & - & & & & & & \\
Health & $0.743^{*}$ & $0.633^{*}$ & - & & & & & \\
Having & $0.896^{*}$ & $0.781^{*}$ & $0.539^{*}$ & - & & & & \\
Loving & $0.922^{*}$ & $0.820^{*}$ & $0.691^{*}$ & $0.709^{*}$ & - & & & \\
FA & $0.773^{*}$ & $0.668^{*}$ & $0.568^{*}$ & $0.716^{*}$ & $0.731^{*}$ & - & & \\
Absorption & $0.634^{*}$ & $0.582^{*}$ & $0.520^{*}$ & $0.563^{*}$ & $0.577^{*}$ & $0.810^{*}$ & - & \\
Enjoyment & $0.676^{*}$ & $0.552^{*}$ & $0.497^{*}$ & $0.637^{*}$ & $0.656^{*}$ & $0.901^{*}$ & $0.574^{*}$ & - \\
IWM & $0.733^{*}$ & $0.639^{*}$ & $0.499^{*}$ & $0.688^{*}$ & $0.694^{*}$ & $0.929^{*}$ & $0.653^{*}$ & $0.772^{*}$ \\
\hline
\end{tabular}

Keterangan: ${ }^{*} \mathrm{p}<0,001 ; \mathrm{SWB}=$ School Well-Being; FA $=$ Flow Akademik; IWM = Intrinsic Work Motivation

Teknik korelasi yang digunakan pada penelitian ini adalah Pearson's Correlations dan dihitung menggunakan bantuan program JASP. Hasil uji korelasi antar variabel dan antar aspek dapat dilihat pada Tabel 2. Berdasar uji hipotesis pada Tabel 2, diketahui bahwa school well-being danflow academic menunjukkan korelasi dengan nilai $r=0,773$ dan $\mathrm{p}=$ $0,000(\mathrm{p}<0,01)$. Oleh karen itu, dapat dikatakan, terdapat hubungan positif antara school well-being dengan flow akademik yang sangat signifikan. Hal ini sesuai dengan hipotesis yang telah diajukan oleh peneliti. Hal tersebut menunjukkan bahwa jika school well-being pada siswa semakin tinggi, maka flow akademik pun juga semakin tinggi. Begitu pula 
sebaliknya, semakin rendah school well-being pada siswa, semakin rendah juga flow akademik yang ia tunjukkan. Dari hasil korelasi pada Tabel 2, ditunjukkan bahwa seluruh aspek school well-being memiliki korelasi yang signifikan dengan flow akademik yaitu aspek being dengan flow akademik $(r=0,668, \mathrm{p}=0,000)$, aspek Health dengan flow akademik $(r=0,568 ; \mathrm{p}=0,000)$, Having dengan flow akademik ( $r=0.716 ; \mathrm{p}=0.000)$, aspek Loving dengan flow akademik memiliki korelasi tertinggi dengan koefisien korelasi sebesar $(r=0.731 ; \mathrm{p}=0,000)$.

Hasil analisis lanjutan mengenai peranan school well-being terhadap flow akademik dapat dilihat pada tabel 3. Tabel 3 menunjukkan bahwa nilai $F=166,349$ dengan $\mathrm{p}=0.000(\mathrm{p}<0.01)$. Hal ini menunjukkan bahwa school well-being memiliki peranan yang sangat signifikan terhadap flow akademik siswa SMP. Tabel 3 juga menunjukkan bahwa School Well-Being secara signfikan mampu memprediksi Flow Akademik $(\beta=0.401 ; p<0.001)$, dan diperoleh persamaan regresi berikut: $Y=67,386+0.401 X$. Dari Tabel 3, diketahui bahwa hasil dari 'besaran pengaruh' variabel X yaitu school well-being terhadap variabel $\mathrm{Y}$ yaitu flow akademik adalah tergolong tinggi, di mana nilai $\mathrm{R}^{2}$ sebesar 0,598. Dengan demikian, School wellbeing dapat menjelaskan pengaruhnya terhadap flow akademik sebsear 59,8\%, sedangkan 40,2\% flow akademik dipengaruhi oleh variabel lain.

Tabel 3. Koefisien regresi school well-being terhadap flow akademik

\begin{tabular}{lccccc}
\hline \multicolumn{1}{c}{ Model } & B & SE & $\boldsymbol{\beta}$ & $\mathbf{t}$ & $\mathbf{p}$ \\
\hline $\mathrm{H}_{0}$ (Intercept) & 67.386 & 0.802 & & 84.046 & $<0,001$ \\
$\mathrm{H}_{1}$ (Intercept) & 3.730 & 4.962 & & 0.752 & 0,454 \\
School Well-Being & $0.401 * * *$ & 0.031 & $0.773 * * *$ & 12.898 & $<0,001$ \\
\hline${ }^{*}<0,05 .{ }^{* * p}<0,01 .{ }^{* * *} p<0,001$. & & & &
\end{tabular}

\section{DISKUSI}

Berdasarkan uji korelasi, diketahui bahwa terdapat hubungan yang signifikan antara school well-being dengan flow akademik. Hasil analisis telah menunjukkan koefisien korelasi $r$, yaitu sebesar 0,769 dengan nilai signifikansi adalah 0,001 . Oleh karena itu, dapat dikatakan bahwa terdapat hubungan yang positif antara school well-being dengan flow akademik. Hal tersebut mengartikan bahwa jika school well-being pada siswa semakin tinggi maka flow akademiknya juga akan semakin tinggi. Sebaliknya, jika school well-being pada siswa semakin rendah maka flow akademiknya juga akan semakin rendah.

Dari hasil tersebut, dapat diketahui bahwa pada siswa yang bisa merasakan perasaan sejahtera dan bahagia selama mengikuti pembelajaran di sekolah, maka siswa tersebut akan bisa meningkatkan flow akademiknya dalam mengikuti pembelajaran dan menyelesaikan tugas-tugas akademiknya di sekolah. Sebaliknya, jika siswa kurang bisa merasakan memiliki kesejahteraan, kebahagiaan selama mengikuti pembelajaran di sekolah, maka siswa tersebut, kurang bisa meningkatkan flow akademiknya dalam mengikuti pembelajaran dan menyelesaikan tugas-tugas akademiknya di sekolah. School well-being merupakan faktor yang memberikan pengaruh terhadap flow akademik dan juga salah satu konstrak psikologi yang membahas penilaian subjektif siswa terhadap keadaan sekolahnya. Pandangan dan penilaian siswa terhadap sekolah dapat menjadi penentu tingkat school well-being (Konu \& Rimpelä, 2002).

Berdasarkan hasil pada kategorisasi jawaban responden, bisa diketahui bahwa sebagian besar siswa memiliki school well-being dalam kategori rendah sebesar $68 \%$ dan berjumlah sebesar 77 siswa. Dari hal ini bisa diketahui bahwa selama menempuh pendidikan di jenjang SMP, sebagian siswa sudah mempunyai school well-being yang rendah. School well-being rendah ditunjukkan dengan terdapatnya siswa yang kurang mempunyai penilaian atau pandangan yang positif terhadap lingkungan fisik sekolahnya. Berdasarkan hasil pada 
kategorisasi jawaban responden, dapat diketahui bahwa sebagian besar siswa memiliki flow akademik dalam kategori rendah, yaitu sebesar $70 \%$, atau 80 siswa. Flow akademik rendah ditunjukkan dengan terdapatnya siswa yang kurang memiliki kemampuan berkonsentrasi penuh, kurang bisanya siswa merasakan kenyamanan, kesenangan serta rasa bahagia, dan kurang mempunyai motivasi yang dari dalam diri saat melakukan aktivitas pembelajaran dan penyelesaian tugas akademiknya.

Berdasarkan hasil uji korelasi, telah diketahui bahwa terdapat peran yang signifikan school wellbeing terhadap flow akademik. Hasil dari besaran pengaruh variabel X yaitu school well-being terhadap variabel $\mathrm{Y}$, yaitu flow akademik adalah tergolong tinggi, dimana nilai $\mathrm{R}^{2}$ sebesar 0,598. Artinya, School well-being dapat menjelaskan 59, 1\%, flow akademik. Dengan terdapatnya kesejahteraan tersebut, seorang siswa akan merasa antusias dalam melakukan kegiatan pembelajaran dan penyelesaian tugas akademiknya, maka siswa diharapkan bisa meningkatkan flow akademiknya. Selain itu siswa yang memiliki school well-being positif akan mendapatkan manfaat positif salah satunya adalah kreativitas dan kualitas belajar yang baik (Amanillah \& Rosiana, 2017).

Hasil penelitian ini mendukung temuan dari Dariyo (2018), yang membuktikan bahwa school well-being adalah faktor yang bisa mempengaruhi keterlibatan akademik siswa di sekolah. Seorang siswa yang bisa merasakan semakin sejahtera selama belajar di sekolah, maka siswa tersebut akan semakin mengembangkan keterlibatan akademik dalam pembelajaran di sekolah. Penelitian ini juga sesuai dengan penelitian oleh Purnomo (2018) yang telah menunjukkan bahwa siswa yang memiliki school well-being yang tinggi akan bisa meningkatkan keinginan yang mendalam dari diri pribadi siswa tersebut untuk selalu memiliki motivasi diri dalam mengikuti pembelajaran di sekolah termasuk mengembangkan berbagai kreativitasnya. Hubungan antara school well-being dengan flow akademik yaitu kepuasan penerimaan dalam school wellbeing dan memandang atau menilai school well- being dengan baik dan positif akan menimbulkan individu memiliki school well-being tinggi dan akan meningkatkan flow akademik siswa. Flow akademik akan membuat individu bisa mengikuti proses pembelajaran dan bisa mencapai tujuan belajar yang baik dan optimal.

Terdapat beberapa aspek untuk menentukan apakah siswa mempunyai school well-being tinggi atau school well-being rendah. Aspek-aspek tersebut antara lain having, loving, being dan health. Siswa yang merasakan kepuasan, kesejahteraan dan kebahagiaan terhadap kondisi lingkungan sekolahnya akan merasa terpenuhi kebutuhan dasarnya di sekolah yang meliputi kondisi sekolah (having), relasi sosial (loving), pemenuhan diri (being), dan kesehatan (health). Dampak dari kondisi ini membuat siswa memiliki perasaan senang, menikmati (enjoyment) yang tinggi, memiliki motivasi dari dalam diri (intrinsic work motivation) yang tinggi, dan memiliki kemampuan dalam penyerapan, keterlibatan (absortion) serta konsentrasi secara penuh yang tinggi. Hal tersebut dapat membuat siswa mengikuti proses pembelajaran dan tujuan belajar yang baik dan optimal (Azizah \& Hidayati, 2015). Pada hasil penelitian ini, school well-being telah memberikan pengaruh terhadap flow akademik. Selain school well-being, terdapat faktor-faktor lain yang memberikan pengaruh terhadap flow akademik yaitu hubungan sosial (orang tua, keluarga, significant other), teman dan waktu luang, kesukarelaan individu, peran sosial, karakteristik kepribadian, aspirasi dan tujuan (Anggreni \& Immanuel, 2020).

Peneliti melihat beberapa kelemahan dalam penelitian ini, yaitu tentang waktu penelitian yang kurang tepat karena pada saat penelitian dilakukan bertepatan dengan libur sekolah. Selain itu, pengambilan data tidak bisa dilakukan secara tatap muka, dikarenakan kondisi dan situasi yang tidak memungkinkan yaitu adanya pandemik virus COVID-19. Penelitian ini hanya menggunakan jenjang subjek pada jenjang SMP yang seharusnya bisa menggunakan seluruh siswa SMP atau jenjang di bawahnya maupun di atasnya yaitu SD, SMA, dan jenjang mahasiswa. Subjek yang berbeda bisa 
menghasilkan wawasan dan hasil yang berbeda sehingga masih banyak kekurangan dan keterbatasan dalam memberikan informasi.

Saran bagi peneliti berikutnya yang mungkin merasa tertarik untuk melakukan penelitian dengan tema yang sama, dapat meneliti siswa yang berada di bawah maupun atas jenjang SMP, misalnya SD, SMA, dan atau mahasiswa. Subjek yang berbeda bisa menghasilkan wawasan dan hasil yang berbeda.

Saran bagi siswa, siswa dapat meningkatkan flow akademik seperti memiliki kemampuan dan ketrampilan pribadi untuk bisa berkonsentrasi sepenuhnya dan terlibat secara mendalam, mempunyai perasaan nyaman, bahagia serta memiliki motivasi dari dalam diri ketika mengikuti pembelajaran disekolah. Upaya untuk meningkatkan school wellbeing pada siswa, di antaranya upaya peningkatan kualitas diri siswa dalam menjalankan tugas serta fungsinya disekolah, hal tersebut dapat dilakukan dengan cara, siswa bisa meningkatkan interaksi dan menjalin hubungan sosial yang lebih kuat dan baik. Menjalin interaksi dan hubungan yang baik dengan orang tua, keluarga, teman, dan guru dengan maksud dan tujuan untuk penguatan karakter interaksi dan hubungan sosial, supaya siswa tersebut bisa lebih terlibat dan memiliki makna atau bisa memaknai pelajaran yang mereka dapatkan dan siswa juga bisa memperoleh dukungan sehingga akan bisa menumbuhkan serta meningkatkan perasaan bahagia dan sejahtera pada siswa.

Kemudian terdapat partisipasi sosial oleh siswa, seperti siswa bisa mengikuti kegiatan-kegiatan sukarela yang diharapkan akan bisa menumbuhkan hubungan yang positif dengan individu lain. Siswa juga harus memahami, mengerti dan memiliki sebuah komitmen agar dapat mengatur tujuan hidup yang diinginkannya, yang bermanfaat membantu siswa agar memiliki pemahaman tentang arti hidupnya dan bisa jadi membantu mengatasi masalahnya, hal ini bisa dilakukan dengan meningkatkan emosi positif yang ada pada diri siswa dengan cara bisa berpikir positif terhadap segala situasi yang sedang dihadapinya. Bagi Sekolah diharapkan bisa selalu memberikan perhatian terhadap school well- being siswa, dan tidak hanya dibebankan pada siswa saja dalam meningkatkan flow akademik siswa. Hal tersebut bisa dilakukan pihak sekolah seperti, sekolah bisa memenuhi kebutuhan dasar siswa disekolah seperti having, loving, being, dan health sehingga bisa membantu siswa mencapai kondisi flow dan mengalami flow akademik saat mengikuti proses pembelajaran dan aktivitas akademiknya disekolah. Sehingga siswa akhirnya mempunyai penilaian yang baik dan pandangan yang positif terhadap lingkungan sekolahnya, dan bisa memiliki school well-being yang tinggi sehingga bisa meningkatkan flow akademik siswa dan siswa bisa mencapai tujuan akademik yang ingin diraih.

Bagi peneliti selanjutnya, penelitian yang berkaitan dengan school well-being dan flow akademik adalah topik yang bagus dan sesuai untuk diteliti. Belum banyak penelitian yang dilakukan yang berkaitan dengan topik school well-being dan flow akademik di Indonesia, banyak penelitian tentang flow akademik namun dengan variabel yang mempengaruhinya berbeda, maka hal ini sangat menarik untuk dilakukan penelitian dengan topik serupa. Jumlah subjek penelitian ini juga kurang banyak, bagi peneliti selanjutnya disarankan untuk melakukan penelitian dengan jumlah subjek yang lebih banyak, karena SMP Muhammadiyah 10 adalah sekolah yang baru berdiri dan jumlah keseluruhan siswa yang tidak banyak sehingga pengambilan subjek siswa terbatas.

\section{SIMPULAN}

Berdasarkan pada pembahasan hasil penelitian yang telah diuraikan di atas, dapat ditarik kesimpulan bahwa terdapat hubungan positif antara school wellbeing dengan flow akademik pada siswa SMP X Hipotesis pada penelitian ini dapat diterima. Semakin tinggi school well-being pada siswa, maka akan semakin tinggi juga flow akademik pada siswa SMP X. Begitu pun sebaliknya, semakin rendah school well-being pada siswa, maka akan semakin rendah juga flow akademik pada siswa. Pada hasil kategori ditemukan siswa masuk pada kategorisasi flow akademik dan school well-being yang cenderung 
rendah. Besaran pengaruh variabel school well-being terhadap flow akademik adalah tergolong tinggi.

\section{DAFTAR PUSTAKA}

Alfarabi, A. (2017). Hubungan tingkat religiusitas dengan flow akademik pada siswa. Skripsi, $1-$ 40. http://eprints.umm.ac.id/44022/

Aini, N.Q., Ifliandra, I., \& Saripah, I. (2019). Aspek-aspek Flow Akademik. Jounral of Innovative Counseling: Theory, Practice, \& Research, 3(2), 43-52.

Amanillah, S. \& Rosiana, D. (2017). Hubungan School Well-Being Dengan Motivasi Belajar Pada Siswa Kelas XI MA X. Prosiding Psikologi, 3(2),542-547.

Anggreni, N.M.S. \& Immanuel, A.S. (2020). Model School Well-Being sebagai Tatanan Sekolah Sejahtera Mahasiswa. Psikobuletin: Buletin Ilmiah Psikologi, 1(3), 146-156

Azizah, A \& Hidayati, F. (2015). Pesyesuaian Sosial dan School Well-Being: Studi Pada Siswa Pondok Pesantren yang Bersekolah di MBI Ammanatul Ummah Pacet Mojokerto. Jurnal Empati, 4(4), 84-89.

Dariyo, A. (2018). Peran School Well Being dan Keterlibatan Akademik dengan Prestasi Belajar pada Siswa Sekolah Dasar. Journal Psikogenesis, 5(1). https://doi.org/10.24854/jps.v5i1.490

European Commission. (2014). ey Data on Early Childhood Education and Care in Europe 2014 Edition. Eurdice and Eurostat Report. Luxembourg: Publications Office of the European Union.

Gatari, A. (2020). Hubungan Stres Akademik dengan Flow Akademik. Cognicia, 8(1):

Konu, A., \& Rimpelä, M. (2002). Well-being in schools: a conceptual model. Health Promotion International, 17(1), 79-87. https://doi.org/10.1093/heapro/17.1.79

Mubasyiroh, P. (2017). Mental Emotional Symptoms Deteminant Of Junior-Senior High School Students In Indonesia 2015. Buletin Penelitian Kesehatan, 45(2), 103-112

Parman, R. (2019). Pengaruh Efikasi Diri,
Dukungan Sosial, dan Flow Akademik Terhadap Keterlibatan Siswa Di Sekolah. Thesis. Universitas Muhammadiyah Malang.

Prihandrijani, E. (2016). Pengaruh motivasi berprestasi dan dukungan sosial terhadap flow akademik pada siswa SMA "X" di Surabaya. Thesis. Universitas Airlangga.

Purnomo. (2018). Hubungan Antara School Well Being dengan Motivasi Berprestasi pada Siswa Kelas XI di Sekolah Menengah Atas. Skripsi. Universitas Sanata Dharma.

Putri, E.M.R. (2016). Hubungan antara Dukungan Sosial dan Flow Akademik Dengan Prestasi Belajar Matematika SMA. Jurnal Calyptra: Jurnal Ilmiah Mahasiswa Universitas Surabaya, $5(1)$.

Rubini, A., \& Utami, I. (2015). Studi Deskriptif Mengenai Profil Flow dalam Bekerja pada Alumni Psikologi Unisba Menyelesaikan Studi dengan Lulus Cum Laude. Prosiding Psikologi, 1(2), 205-211. http://karyailmiah. unisba.ac.id/index.php/psikologi/article/view/ 1193.

Salanova, M., Bakker, A. B., \& Llorens, S. (2006). Flow at work: Evidence for an upward spiral of personal and organizational resources. In Journal of Happiness Studies, 7(1), 1-22 https://doi.org/10.1007/s10902-005-8854-8

Santoso, M (2014). Self-Efficacy dan Flow Akademik Ditinjau dari Temporal Motivation Theory pada Mahasiswa Fakultas Psikologi. Calyptra: Jurnal Ilmiah Mahasiswa Universitas Surabaya, 3(1).

Satici, B (2020). Social Exclusion and adolescents well-being:Stress, school satisfaction, and academic self-eficacy as multiple mediators. The Educational and Developmental Psychologist, 37(1), 67-74.

Sentana, M.A. \& Kumala, I, D. (2017). Agresivitas dan Kontrol Diri pada Remaja di Banda Aceh. Jurnal Sains Psikologi, 6(2), 51-55

Shernoff, D. J., Csikszentmihalyi, M., Schneider, B., \& Shernoff, E. S. (2003). Students engagement in high school classrooms from the perspective 
of flow theory. School Psychology Quarterly, 18(2), 158-176.

Yuwanto, L. (2013). The Nature of Flow, dalam Yuwanto, L (Ed) The Nature of Flow, (1-8), Sidoarjo: Penerbit Dwiputra Pustaka Jaya.
Naskah masuk : 11 September 2021

Naskah diterima: 13 Desember 2021 